\title{
AIR AND WATER-VAPOUR CONVECTION IN SNOW
}

\author{
by
}

\author{
N. KLEVER
}

Federal Institute for Geosciences and Natural Resources, Alf red-Benk-Haus, Stilleweg 2, D-3000 Hannover 1, FDR

\begin{abstract}
Heat and mass transport by an air and water-vapour mixture (pore air) in snow due to thermal convection has been computed. It can be shown theoretically that thermal convection is always occuring in newly fallen snow, but never occurs in snow with rounded grains. Rayleigh numbers of depth hoar and partly settled snow are close to the critical Rayleigh number, therefore a small change in one or more of the snow parameters will decide whether there is convective or conductive heat transport.

The influence of thermal convection on the mass transport rates of water vapour in snow is computed based on the assumption of the ventilation approach. Although thermal convection occurs more often than previously assumed, its influence amounts only to about $2-3 \%$.
\end{abstract}

\section{INTRODUCTION}

Since the early papers of Paulcke (1934), Seligman (1936) and Bader (1939) several authors have tried to understand the role of the flux of water-vapour on the metamorphism in dry snow. The influence of thermal convection of the pore air on metamorphism has been a matter of question for a long time (de Quervain 1963). Yen (1962, 1963) and de Quervain (1972) have introduced a term for moisture exchange due to ventilation to the equation of mass balance. A detailed dimensional analysis of heat and mass transfer in a snowpack was published by Male and others (1972). They concluded that the development of general analytical, numerical or experimental models will prove impractical, and suggested that field studies of situations involving a restricted number of parameters is the only tractable approach. First measurements of air circulation in snow were made by Neher (1939). Trabant and Benson $(1972,1973)$ were among the first to attribute their high observed mass flux to thermal convection. Akitaya (1974) examined the possibility of thermal convection in snow by laboratory experiments. As far as I know only one significant quantitative study of theoretical models has been published until now (Palm and Tveitereid 1979). Both Akitaya and Palm and Tveitereid postulated that thermal convection only occurs in extreme situations like coarse grained old snow with strong vertical temperature gradients and large air permeabilities. A weakness of Palm and Tveitereid's paper is that the models are based on permeability data of Kuroiwa (1968), which are only classified between fine and coarse grained snow. Further, these authors took the same thermal conductivity for all different kinds of snow.

In the last years the interest in problems connected with pore air in snow has increased, as shown by the papers of Powers and others (1985, this issue) and Klever (1983, 1984).

\section{GOVERNING EQUATIONS AND NUMERICAL METHOD}

Fluid flow in porous media is governed by the equations of conservation - energy, momentum and mass in combination with the equation of state. Combining these equations and introducing the streamfunction $\Psi$ by:

$$
\mathrm{U}_{\mathrm{X}}=\frac{\partial \Psi}{\partial \mathrm{z}} \quad \mathrm{U}_{\mathrm{z}}=-\frac{\partial \Psi}{\partial \mathrm{x}}
$$

lead to the following coupled equations

$$
\begin{gathered}
\frac{\partial}{\partial x}\left[\frac{v}{K_{z z}} \frac{\partial \Psi}{\partial x}\right]+\frac{\partial}{\partial z}\left[\frac{v}{k_{x x}} \frac{\partial \Psi}{\partial z}\right]-R a \frac{\partial}{\partial x}[T g]=0 \\
\frac{\partial}{\partial x}\left[\left[\Phi \lambda_{x x}^{f}+(1-\Phi) \lambda_{x x}^{m}\right] \frac{\partial T}{\partial x}\right]+\frac{\partial}{\partial z}\left[\left(\Phi \lambda_{z z}^{f}+(1-\Phi) \lambda_{z z}^{m}\right] \frac{\partial T}{\partial z}\right]+ \\
+\frac{\partial \Psi}{\partial x} \frac{\partial T}{\partial z}-\frac{\partial \Psi}{\partial z} \frac{\partial T}{\partial x}=0
\end{gathered}
$$

$\checkmark$ kinematic viscosity

T Temperature

$\Phi$ porosity

g gravitational acceleration

o fluid density

$\underline{v}$ velocity vector

$\mathrm{U}_{\mathrm{x}}, \mathrm{U}_{\mathrm{z}}$ components of the mass velocity vector $\underline{\mathrm{u}}=$ p $\underline{\mathrm{v}}$

$k_{x x}, k_{z z}$ components of the permeability tensor

$\lambda_{x x}, \quad \lambda_{z z}$ components of the thermal conductivity tensor (index m: medium -f: fluid).

All variables in these equations have been made dimensionless by normalizing factors, indicated by primes (Table 1). This process defines the dimensionless Rayleigh number in the following way:

$$
\mathrm{Ra}=\frac{\rho^{*} \alpha^{*} \mathrm{~T}^{*} \mathrm{~g}^{*} \mathrm{k}^{*} \mathrm{z}^{*} \mathrm{c}^{*}}{v^{*} \lambda^{*}}
$$

TABLE 1. NORMALIZING FACTORS FOR THE SNOW MODELS. LENGTH AND TEMPERATURE ARE MEAN VALUES FOR SNOW LAYERS: PERMEABILITY AND THERMAL CONDUCTIVITY ARE MEAN VALUES DERIVED FROM THE EQUATIONS OF SHIMIZU AND DEVAUX. THE PROPERTIES OF THE FLUID ARE TAKEN FROM STANDARD AIR PROPERTIES.

$$
\begin{aligned}
& \text { density } \quad \rho^{*}=1.3 \mathrm{~kg} / \mathrm{m}^{3} \\
& \text { thermal expansion coeff. } \alpha^{*}=3.6710^{-3} 1 /{ }^{\circ} \mathrm{C} \\
& \text { dynamic viscosity } \quad \mu^{*}=1.710^{-5} \mathrm{PaS} \\
& \text { kinematic viscosity } \quad v^{*}=\mu^{*} / \rho^{*}=1.30810^{-5} \mathrm{~m}^{2} / \mathrm{s} \\
& \text { gravitational acceleration } \mathrm{g}^{*}=9.81 \mathrm{~m} / \mathrm{s}^{2} \\
& \text { specific heat (const. vol.) } \mathrm{c}^{*}=717 \mathrm{~J} / \mathrm{kg}{ }^{\circ} \mathrm{C} \\
& \text { length } \quad \mathrm{z}^{*}=1 \mathrm{~m} \\
& \text { temperature } \quad \mathrm{T}^{*}=10^{\circ} \\
& \text { permeability } \quad \mathrm{k}^{*}=10^{-7} \mathrm{~m}^{2} \\
& \text { thermal conductivity } \quad \lambda^{*}=0.1 \mathrm{~W} / \mathrm{m}^{\circ} \mathrm{C}
\end{aligned}
$$


When simulating thermal convection of pore air in snow with the help of the above equations the influence of the following physical processes is neglected:

- the volume change due to compressibility of a gas

- the process of diffusion of water-vapour and

- phase exchanges solid-fluid-gas.

Concerning the first simplification it can be argued that this is acceptable for velocities that are small compared with the speed of sound. The others imply that mass transport by metamorphism cannot be taken into consideration within the numerical calculations. Therefore no conclusions concerning net density changes are possible.

The numerical method used was a finite-difference approximation to the differential equations. To avoid numerical instabilities the Il'in scheme is used (Gorenflo and Kiesner 1982). This method is extended to simulate sloped regions with a constant or changing gradient. A detailed description of the theoretical and numerical procedure is given by Klever (1984).

\section{RAYLEIGH NUMBER AND BOUNDARY CONDITIONS}

An example for normalizing factors is given in Table I. From these factors a Rayleigh-number can be computed to $\mathrm{Ra}=25.656$. All models have the same Rayleigh number. The definite change between conductive and convective heat transport is described by the critical Rayleigh number. To compute models for different types of snow, permeability and thermal conductivity are introduced numerically by functions and not by Rayleigh number. This formulation leads to different critical Rayleigh numbers for the different types of snow. This procedure seems to be legitimized by its usefulness for comparing dimensionless results as well as for the introduction of lateral variation of permeability and conductivity (Klever 1984). The critical Rayleigh number $\mathrm{Ra}_{\mathrm{c}}$ used in this paper is connected to the critical Rayleigh number $\mathrm{Ra}_{\mathrm{nc}}$ normally used in literature by

$$
R a_{c}=\frac{k^{*}}{k} \frac{\lambda_{t}}{\lambda^{*}} R a_{n c}
$$

$\lambda_{t}$ is the thermal conductivity of the whole system defined by

$$
\lambda_{t}=(1-\Phi) \lambda_{g}+\Phi \lambda_{f}
$$

where $\lambda_{s}$ and $\lambda_{f}$ refers to the thermal conductivity of snow and fluid (air).

$R a_{n c}=27.1$ is the critical Rayleigh number of the models with the following boundary conditions (Ribando and Torrance 1976): temperature is kept constant at the top and bottom and adiabatic conditions exist on both sides. The boundary conditions for the streamfunction are a permeable top and impereable boundaries elsewhere. This should simulate a normal snowcover under normal meteorological conditions.
For our models $\lambda_{\mathrm{s}}$ and $\mathrm{k}$ were computed by

$$
\begin{aligned}
\lambda_{\mathrm{s}} & =2.93 \mathrm{\rho}_{\mathrm{g}}^{2} 10^{-6}+2.9310^{-2}\left[\mathrm{~W} / \mathrm{m}^{\circ} \mathrm{C}\right] \text { Devaux } 1933 \\
\mathrm{k} & =0.077 \mathrm{~d}^{2} \mathrm{e}^{-7.8(\rho \mathrm{s} / \rho \mathrm{W}}\left[\mathrm{m}^{2}\right] \text { Shimizu } 1970
\end{aligned}
$$

where $d$ means grain size and $\lambda_{f}$ was assumed to be $0.0026 \mathrm{~W} / \mathrm{m}^{\circ} \mathrm{C}$ (standard air).

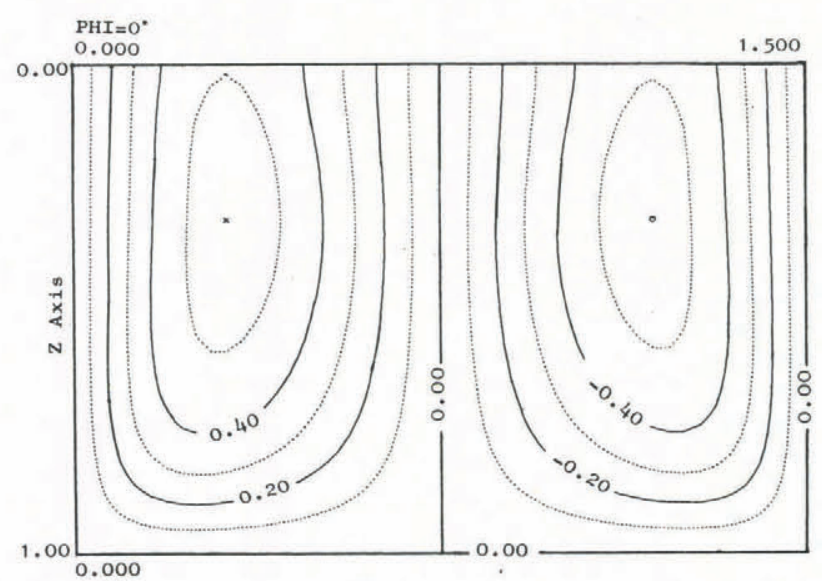

Fig.1a. Normalized stream function $\Psi / \Psi^{*}[1]$ (where $\Psi^{*}=$ $0.139 \mathrm{~g} / \mathrm{m} \mathrm{s}$ ) of model TSM-N-02 with newly fallen snow. The Rayleigh number of this model is $\mathrm{Ra}=25.656$ and the critical Rayleigh number is here $\mathrm{Ra}_{\mathrm{c}}=6.295$ (see Table 2).

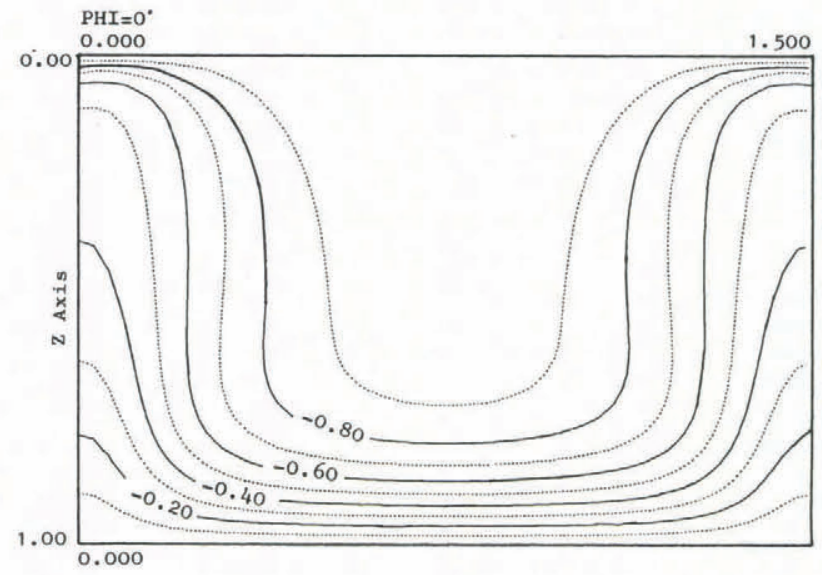

\begin{tabular}{|c|c|c|c|c|c|c|c|}
\hline snow & symbol & $\begin{array}{l}\text { Grain } \\
\text { size } \\
\text { d } \\
\mathrm{mm}\end{array}$ & $\begin{array}{c}\text { Density } \\
\rho_{\mathrm{s}} \\
\mathrm{Kg} / \mathrm{m}^{3}\end{array}$ & $\begin{array}{c}\text { Porosity } \\
\Phi\end{array}$ & $\begin{array}{c}\text { Permeability } \\
\mathrm{k} / \mathrm{k}^{*}\end{array}$ & $\begin{array}{c}\text { Thermal } \\
\text { Conductivity } \\
\lambda_{\mathbf{g}} / \lambda^{*}\end{array}$ & $\begin{array}{c}\text { Critical } \\
\text { Rayleigh No } \\
\mathrm{Ra}_{c}\end{array}$ \\
\hline newly & & & & & & & \\
\hline fallen snow & ++ & 1 & 100 & 0.9 & 0.353 & 0.082 & 6.295 \\
\hline $\begin{array}{c}\text { partly } \\
\text { settled snow }\end{array}$ & 11 & 1 & 200 & 0.8 & 0.162 & 0.314 & 52.527 \\
\hline rounded grains & $\cdot$. & 1.25 & 350 & 0.6 & 0.0785 & 1.568 & 541.309 \\
\hline depth hoar & $\wedge \wedge$ & 3 & 270 & 0.7 & 0.843 & 0.747 & 24.014 \\
\hline
\end{tabular}

Fig.1b. Normalized temperature $\mathrm{T} / \mathrm{T}^{*}[1]$ (where $\mathrm{T}^{*}=10^{\circ} \mathrm{C}$ ) of model TSM-N-02.

TABLE 2. 


\section{MODELS}

Mean values for density, porosity and crystal size (Table 2) have been taken from statistics of seasonal snowcover at Weißfluhjoch/Davos (de Quervain 1980/81). Permeability, thermal conductivity and the critical Rayleigh number (Table 2) have been computed from these values according to the equations given above. The presence of deviations from these mean values was considered by changing the normalizing factors and therefore the Rayleigh number $\mathrm{Ra}$.

It is remarkable that in snow with rounded grains no sensible variation of the parameters can change $\mathrm{Ra}$ to exceed the critical Rayleigh number $\mathrm{Ra}$. Therefore no convection will occur. Just the opposite is true in the case of newly fallen snow: here the Rayleigh number $\mathrm{Ra}$ will be greater than the critical Rayleigh number $\mathrm{Ra}$ for all variations of the parameters in the admissible range. Therefore convection always seems to be possible in newly fallen snow. However, in the case of partly settled snow and depth hoar slight changes in some parameters can have a great bearing on whether convection occurs or not.

In Figure 1 the normalized streamfunction and temperature are shown for a model with newly fallen snow. Using the factors from Table 2 the velocity of pore air in this model can be computed to $0.31 \mathrm{~mm} / \mathrm{s}$. The maximum velocity is computed from a depth hoar model (not shown here) to $4.2 \mathrm{~mm} / \mathrm{s}$. Assuming that the ventilation approach (Colbeck 1983) can give a first approximation to the mass transport by vapour, this velocity has only a small influence: from the ventilation factor an increase of the mass transport rate is computed only to $2.8 \%$.

From theory and experiments it is known that convection always occurs in sloped regions (Combarnous and Bories 1975). These authors have shown that for convection in sloped layers, different types of convective cells are occurring (Figure 2). Because of the large extent of the cells in unicellular flow region, the experiments of Neher

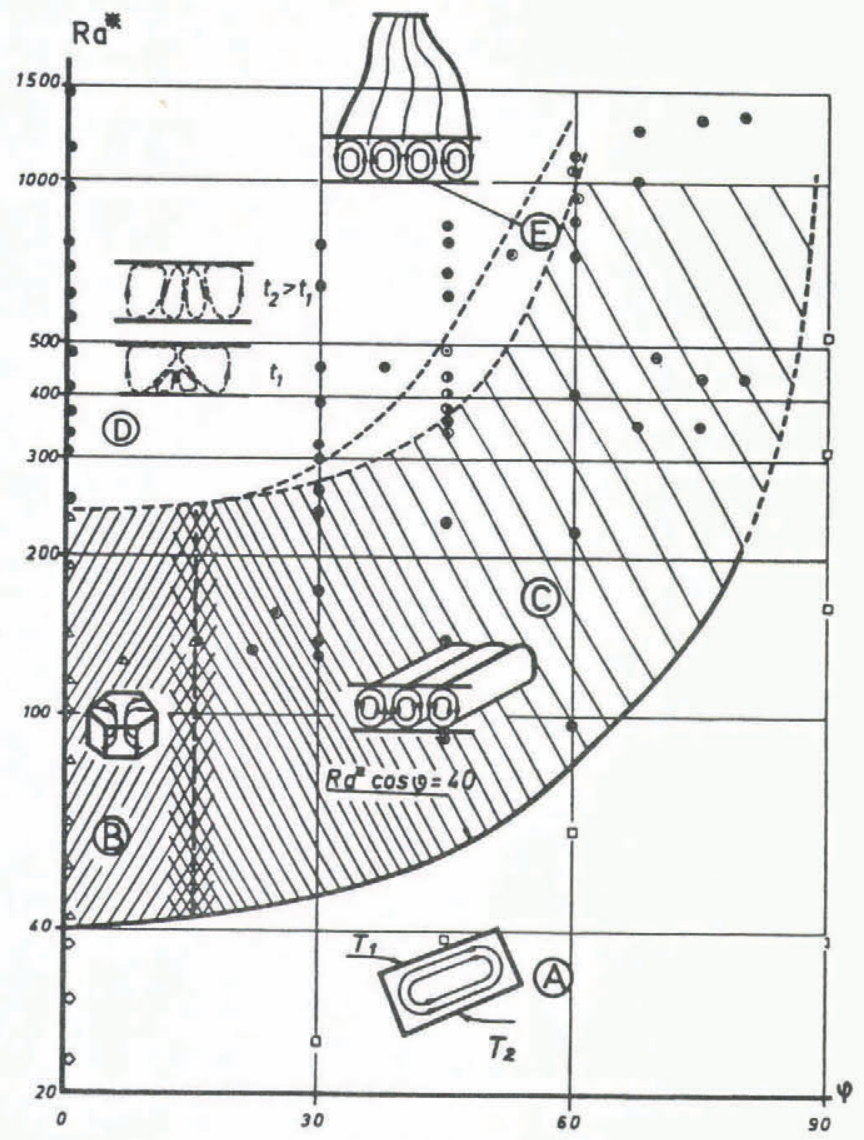

Fig.2. Different types of convective cells in a sloped layer as functions of the experimental conditions ( $\Psi, \mathrm{Ra})$ : $\mathrm{A})$ unicellular flow, B) polyhedral cells, C) longitudinal stable coils, D) fluctuating regime, and E) oscillating longitudinal coils (from Combarnous and Bories 1975).
(1939) can therefore approximately be re-interpreted as a hint at convection in sloped regions.

\section{DISCUSSION}

It can be seen from Table 2 that thermal convection in snow occurs more often as previously assumed. The application of the ventilation approach as a first approximation to the mass transport shows that the computed velocities have only a mean influence of about $2-3 \%$ on the mass transport by vapour. On the other hand, based on a paper by Keller and Hallett (1982), Colbeck (1983) suggests an effect of thermal convection on crystal shape. Starting from this idea and comparing the schematic picture of Wakahama (1968) (Figure 3) with a convective cell, I believe that thermal convection may be the initial state of the occurrence of the drainage of melt water or water channels in the early melt season. There are some

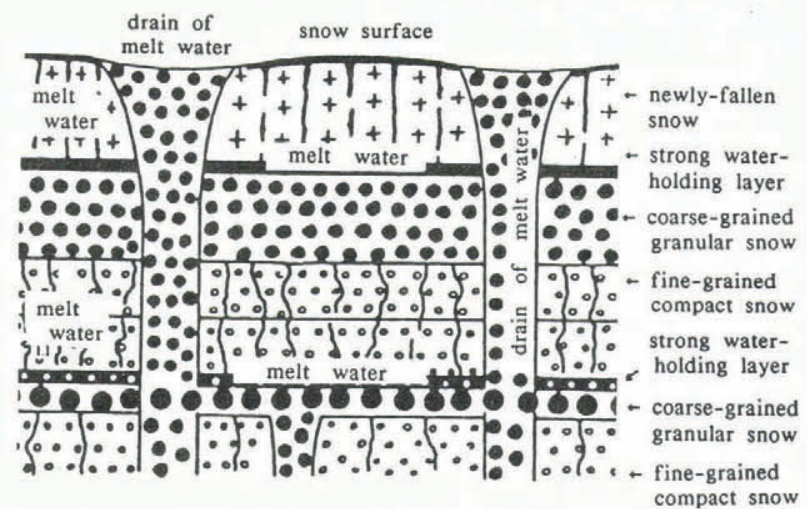

Fig.3. Schematic representation of the layered structure in a snow cover in the early melt season. Large "drains of melt water or water channel" are often found in the snow cover as shown in this figure (from Wakahama 1968).

objections to this suggestion: (1) the invariance of the geometry of the percolation channels as compared to the possible variability of the geometry of the convection cells due to different snow layer depths and due to transient state of convection, (2) the occurrence of the channels in snow layers, where convection seems very unlikely, and (3) more plausible mechanisms such as radiation and melting effects. However the obvious similarity remains, especially in the case of a sloped region if the longitudinal stable coils of the cell-type classification of Combarnous and Bories (1975) are taken into consideration. Much more work has to be done to prove or disprove this suggestion.

\section{REFERENCES}

Akitaya E 1974 Studies on depth hoar. In International Association of Hydrological Sciences Publication 114, Symposium on Snow Mechanics: 42-47

Bader H 1939 Mineralogische und strukturelle Charakterisierung des Schnees und seiner Metamophose, In Bader $\mathrm{H}$ and others (eds) Der Schnee und seine Metamorphose. Beiträge zur Geologie der Schweiz Geotechnische Serie Hydrologie, Lieferung 3. Bern, Kümmerly und Frey: 3-61

Bader H, Haefeli R, Bucher E, Neher J, Eckel O, Thomas Chr 1939 Der Schnee und seine Metamorphose. Beiträge zur Geologie der Schweiz Hydrologie, Lieferung 3. Bern, Kümmerly und Frey

Benson C S, Trabant D C 1973 Field measurements on the flux of water vapour through dry snow. In Proceedings of the International Symposium on The Role of Snow and Ice in Hydrology, Banff, 6-13.9.1972. Banff, World Meteorological Organization (WMO), International Association of Hydrological Sciences (IAHS), UNESCO: 291-298

Colbeck S C 1983 Theory of metamorphism of dry snow. Journal of Geophysical Research 88, C9: 5475-5482

Combarnous M, Bories S A 1975 Hydrothermal convection in saturated porous media. Advances in Hydro-science 10: $231-307$ 
Devaux J 1933 L'economie radio-thermique des Champs de neige et des glaciers. Annales de Physicae 10, 20: 5-67

Gorenflo R, Kiesner St 1982 Über das Il'in -Differenzenverfahren für die Diffusions- KonvektionsGleichung. International Series for Numerical Mathematics (ISNM) 58: 73-89

Keller V W, Hallett J 1982 Influence of air velocity on the habit of ice crystal growth from the vapor. Journal of Crystal Growth 3 60: 91-106

Klever N 1983 Konvektion von Wasserdampf im Schnee? Paper, held at 13. Int. Polartagung, Bamberg, 4-7 Oktober $1983,15 \mathrm{p}$

Klever N 1984 Stationäre Konvektion in porösen Medien - numerische Untersuchungen an unterschiedlichen Fragestellungen aus der Hydrothermik und der Schneemetamorphose. Berliner Geowissen-schaftliche Abhandlungen, Reihe B, Heft 11, $114 \mathrm{p}$

Kuroiwa D 1968 Liquid permeability of snow. Low Temperature Science A, 26: 29-52

Male D H, Norum D I, Besant R W 1972 A dimension analysis of heat and mass transfer in a snowpack. Proceedings of the International Symposium on The Role of Snow and Ice in Hydrology, Banff 6-13.9.1972. Banff, World Meteorological Organization (WMO), International Asociation of Hydrological Sciences (IAHS), UNESCO : 258-290

Neher J 1939 Schneeuntersuchungen im Gelände. In Bader and others (eds) Der Schnee und seine Metamorphose. Beiträge zur Geologie der Schweiz Geotechnische Serie Hydrologie, Lieferung 3. Bern, Kümmerly und Frey: 255-272

Palm E, Tveitereid M 1979 On heat and mass flux through dry snow. Journal of Geophysical Research 84: 745-749

Paulcke W 1934 Eisbildungen 1. Der Schnee und seine Diagenese. Zeitschrift fur Gletscherkunde $\mathrm{XXI}(4 / 5)$ : 259-282

Powers D J, Colbeck S C, O'Neill K 1984 The role of thermal convection in snow metamorphism. Annals of Glaciology 6: 43-47

de Quervain M 1963 On the metamorphism of snow. In Kingery W D (ed) Ice and Snow. Cambridge, Mass., MIT Press: $377-390$

de Quervain M 1972 Snow structure, heat and mass flux through snow. Proceedings of the International Symposium on The Role of Snow and Ice in Hydrology, Banff, 6-13.9.1972. Banff, World Meteorological Association (WMO), International Association of Hydrological Sciences (IAHS), UNESCO: 203-225

de Quervain M 1980/81 Schneekunde, Lawinenkunde, Lawinenschutz. Skript einer Einführungsvorlesung, gehalten an der ETH Zürich, im WS 80/81 (13. Ausgabe)

Seligman G 1936 Snow structure and ski fields. London, MacMillan

Shimizu H 1970 Air permeability of deposited snow. Contributions from the Institute of Low Temperature Science, A, 22: 1-32

Trabant D, Benson C 1972 Field experiments on the development of depth hoar. In Doe B R, Smith D K, Gruner J W (eds) Studies in Mineralogy and Precumbrian Geology, Geological Society of America Memoir 135: 309-322

Wakahama G 1968 The metamorphism of wet snow. General Assembly of Bern, 25.9-7.10.1967. Commission of Snow and Ice. Reports and Discussions. Word W (ed), Gentbrugge. IAHS Publ. 79: 370-379

Yen Y C 1962 Effective thermal conductivity of ventilated snow. Journal of Geophysical Research 67(3): 1091-1098

Yen Y C 1963 Heat transfer by vapour transfer in ventilated snow. Journal of Geophysical Research 68(4): 1093-1101 